ІНТЕНСИФІКАЦІЯ ІННОВАЦІЙНОЇ ДІЯЛЬНОСТІ ЯК ВАЖЛИВА СКЛАДОВА
ПІДВИЩЕННЯ ЕКОНОМІЧНОЇ БЕЗПЕКИ ПІДПРИЄМСТВА

\title{
INTENSIFICATION OF INNOVATIVE ACTIVITIES AS AN IMPORTANT CONSTITUENT OF IMPROVEMENT OF ECONOMIC SECURITY OF THE ENTERPRISE
}

УДК 65.012.45:108

https://doi.org/10.32843/infrastruct37-55

\author{
Продіус 0.І. \\ к.е.н., доцент, \\ завідувач кафедри менеджменту \\ Одеський національний політехнічний \\ університет \\ Цибулько А.О. \\ Одеський національний політехнічний \\ університет
}

\begin{abstract}
У статті досліджено концептуальні основи економічної безпеки підприємства задля виключення або зменшення ризику можливих несприятливих подій та їх наслідків в управлінському, науково-освітньому процесах і в процесах управління майном та персоналом. Доведено, що вжиті заходи щодо виконання вимог правил та інструкцій економічної безпеки повинні мати попереджувальний, профрілактичний, а також практичний характер. Висвітлено роль інновацій у забезпеченні конкурентоспроможності та економічної безпеки підприємства. Визначено, що високі результати реалізації інноваційних проєктів і програм можуть досягатися за умов фоомування висококвалісрікованої проєктної команди, основою якою мають стати інноваційні менеджери. За системного підходу обгрунтовано структуру системи економічної безпеки підприємства за фуннціональними складовими, які найбільше сприяють ефрективному використанню наявних ресурсів та підвищенню захищеності від внутрішніх та зовнішніх економічних загроз в умовах інтенсифрікації інноваційних прочесів.

Ключові слова: економічна безпека підприємства, інновації, інноваційна діяльність, інноваційний менеджер, фрункціональні складові, внутрішні та зовнішні загрози.
\end{abstract}

В статье исследованы концептуальные основы экономической безопасности предприятия с целью исключения или умень- шения риска возможных неблагоприятных событий и их последствий в управленческом, научно-образовательном процессах и в процессах управления имуществом и персоналом. Доказано, что принятые меры по выполнению требований правил и инструкций экономической безопасности должны носить предупредительный, профрилактический, а также практический характер. Освещена роль инноваций в обеспечении конкурентоспособности и экономической безопасности предприятия. Определено, что высокие результаты реализации инновационных проектов и программ могут достигаться в условиях формирования высококвалифицированной проектной команды, основой которой должны стать инновационные менеджеры. При системном подходе обоснована структура системы экономической безопасности предприятия по фуункциональным составляющим, наиболее способствующим эсрфективному использованию имеющихся ресурсов и повышению защищенности от внутренних и внешних угроз в условиях интенсификации инновационных процессов.

Ключевые слова: экономическая безопасность предприятия, инновации, инновационная деятельность, инновационный менеджер, функциональные составляющие, внутренние и внешние угрозы.

The article explores the conceptual bases of economic security of an enterprise with the purpose of eliminating or reducing the risk of possible adverse events and their consequences in management, scientific-educational processes and in the processes of property and personnel management. Against the backdrop of intensification of crisis phenomena of different origin in the modern enterprise management system, there is a need to create a unit whose task is to form management actions to ensure the economic security of the enterprise. The fact that economic security is a universal category, which reflects the security of the subjects of socio - economic relations at all levels, starting with the state and ending with each of its citizens, is a confirmation of the great relevance of this problem. The level of economic security depends on how effectively the management of the company avoids possible threats and eliminates the negative effects of certain negative elements of the external and internal environment. Each of the functional components of economic security should reflect the specifics of the implementation of security measures for particular areas of activity of the enterprise, its structural units or resources. It is proved that the measures taken to comply with the requirements of the rules and regulations of economic security must be of a preventive, preventive and practical nature. The role of innovation in ensuring the competitiveness and economic security of the enterprise is highlighted. Thus, the realization of economic security of the enterprise is based on comprehensive provision of innovative processes aimed at increasing their efficiency. Activation of innovative processes implementation at the enterprise depends on such basic factors as: economic, technological, organizational-managerial, legal, professional training of personnel. The influence of these factors depends on the joint efforts of the state, regional authorities and enterprises. It is determined that high results from the implementation of innovative projects and programs can be achieved in the conditions of formation of a highly qualified project team, which should be based on innovative managers. From the standpoint of the systematic approach, the structure of the economic security system of the enterprise by functional components, which contributes to the efficient use of available resources and increased protection against internal and external threats in the conditions of intensification of innovation processes, is substantiated.

Key words: economic security of an enterprise, innovation, innovation, innovation manager, functional components, internal and external threats.

Постановка проблеми. Сучасна ситуація на вітчизняному та світовому ринках характеризується ускладненням комерційних схем, використанням комплексних продуктів, посиленням конкуренції між компаніями. Підприємства стикаються як із зовнішніми, так і з внутрішніми фракторами виникнення кризи, які проявляються у зниженні кількості обігових грошей та труднощах з отриманням кредитів; зміні напрямів діяльності компанії та організаційної структури; зниженні заробітної плати працівників та загального рівня життя; відсутності повного завантаження працівників; загостренні відносин між співвласниками підприємства; збільшенні випадків невиконання договірних обов'язків контрагентів та заборгованостей; зниженні фрінансування заходів, спрямованих на забезпечення економічної безпеки підприємства. 
На фроні активізації кризових явищ різного походження в сучасній системі управління підприємством виникає необхідність створення підрозділу, завданням якого $€$ фрормування управлінських дій для забезпечення економічної безпеки підприємства. Підтвердженням актуальності зазначеної проблеми $є$ той фракт, що економічна безпека $є$ універсальною категорією, яка відображає захищеність суб'єктів соціально-економічних відносин на всіх рівнях: від держави до ії кожного громадянина. Рівень економічної безпеки залежить від того, наскільки ефективно керівництво підприємства уникає можливих загроз і усуває негативні наслідки окремих негативних елементів зовнішнього та внутрішнього середовища. Кожна з функціональних складових економічної безпеки має відображати специфіку вжиття заходів безпеки щодо окремих напрямів діяльності підприємства, його структурних підрозділів або ресурсів. Водночас у сукупності вони повинні гармонійно доповнювати одна одну, створюючи передумови формування цілісної системи забезпечення економічної безпеки.

В сучасних умовах фрункціонування однією 3 основних загроз економічній безпеці підприємства господарюючих суб'єктів є низька інноваційна активність, що обумовлено застосуванням застарілих технологій, недосконалими методами та формами організації виробництва й управління, відсутністю відпрацьованих механізмів інноваційної діяльності, неефективною схемою взаємодії наукових установ 3 комерційними структурами, недосконалістю організаційно-економічного механізму освоєння інновацій.

Аналіз останніх досліджень і публікацій. Значний внесок у розвиток інноваційної діяльності підприємств зробили вітчизняні й зарубіжні вченіекономісти, зокрема В. Александрова, О. Алимов, Ю. Бажал, А. Гальчинский, В. Гєець, Н. Гончарова, М. Денисенко, Ю. Пахомов, М. Туган-Барановський, С. Філиппова, Н. Чухрай, П. Друкер, В. Лівшиц, І. Шумпетер, Е. Тофлер. Наявні наукові дослідження не дають однозначної відповіді щодо чинників підвищення інноваційного потенціалу вітчизняної економіки. Необхідність досліджень у цьому напрямі обумовлює існування таких основних проблем, як недостатньо високий рівень управління інноваційними процесами, що унеможливлює швидке впровадження нововведень; невідповідність потребам ринку праці щодо кількості необхідних фрахівців; невідповідність програм підготовки фрахівців прискореним інноваційним перетворенням, які відбуваються у промисловості.

Проблемам економічної безпеки присвячено багато наукових праць у світовій літературі. Трактування цього поняття вітчизняними та зарубіжними вченими відрізняється різноманітністю підходів за змістом. Найбільш поглибленим вивченням економічної безпеки підприємства займались такі зарубіжні фрахівці, як Е. Олєйнікова, А. Козаченко, В. Пономарьова, А. Ляшенко, Т. Сухорукова, І. Плєтникова. Серед вітчизняних учених вагомий внесок у висвітлення цього питання зробили С. Ілляшенко, Т. Кузенко, С. Міщенко, Г. Козаченко. Дослідженням питань фрінансово-економічної безпеки займались В. Бурцев, О. Василик, К. Горячева, М. Дмітрієва, М. Єрмошенко, Я. Жаліло, Н. Капустін, О. Барановський, Л. Мартюшева, С. Мищенко, Р. Папехін, І. Бланк, М. Погосова, Н. Самбуріна, Р. Руденський, О. Терещенко, С. Шкарлет, Ю. Лисенко, В. Шелест, А. Спиридонов, та інші науковці. Праці цих дослідників заклали наукове підґрунтя для розуміння фрінансової безпеки щодо різних поглядів. Окремим проблемам забезпечення економічної безпеки підприємства присвятили свої роботи відомі дослідники, зокрема О. Ареф'єва, В. Геєць, 3. Герасимчук, В. Духов, Я. Жаліло, С. Злупко, О. Кузьмін, Л. Мельник, І. Михасюк, С. Мочерний, В. Мунтіян, Н. Нижник, С. Покропивний, Г. Ситник, А. Ревенко, О. Терещенко, С. Шкарлет, С. Філиппова, В. Ярочкін.

Незважаючи на досить широкий спектр досліджень щодо проблеми забезпечення економічної безпеки підприємства, вони вимагають комплексного системного узагальнення та визначення їі впливу на інноваційний розвиток підприємства регіону в сучасних умовах господарювання.

Постановка завдання. Метою статті $€$ аналіз ключових напрямів забезпечення економічної безпеки підприємства в контексті досягнення та підтримання ефективного функціонування інноваційної сфрери.

Виклад основного матеріалу дослідження. В сучасних умовах розвиток світової економічної системи обумовлено насамперед інноваційними процесами, які пов'язані зі створенням та впровадженням у виробництво передових досягнень науки й техніки, тому сорера інноваційної діяльності перетворилась на найголовніший ресурс держави, ефективність використання якого визначає динаміку та прогресивність розвитку національного господарства. У зв'язку з цим активізація інноваційної діяльності господарюючих суб'єктів стає необхідною умовою реалізації національних інтересів у системі економічної безпеки підприємства.

Отже, головною метою економічної безпеки підприємства $є$ забезпечення його стійкого й максимально ефрективного ффункціонування нині й забезпечення високого потенціалу розвитку та зростання підприємства в майбутньому. Необхідність постійно підтримувати економічну безпеку обумовлена об'єктивною наявністю для кожного підприємства завдань із забезпечення стабільності функціонування та досягнення головних цілей своєї діяльності. Рівень економічної 
безпеки залежить від того, наскільки ефективно керівництво підприємства уникає можливих загроз та усуває негативні наслідки окремих негативних елементів зовнішнього й внутрішнього середовища. Кожна 3 функціональних складових економічної безпеки підприємства має відображати специфріку вжиття заходів безпеки щодо окремих напрямів діяльності підприємства, його структурних підрозділів або ресурсів. Водночас у сукупності вони повинні гармонійно доповнювати одна одну, створюючи передумови фрормування цілісної системи забезпечення економічної безпеки підприємства [1-3].

Важливою фрункціональною складовою економічної безпеки підприємства сьогодні $€$ інноваційна-інтелектуальна, що націлена на збереження й розвиток інтелектуального потенціалу підприємства, тобто сукупність прав на інтелектуальну власність або ії використання. На відміну від кадрової складової, інноваційно-інтелектуальна носієм інтелектуального капіталу може мати не тільки людину, але й інших носіїв нематеріальних активів. Інтересами інноваційно-інтелектуальної складової є отримання статусу науково-виробничого підприємства, підвищення рівня винахідницької та раціоналізаторської активності, отримання грантів, оперативне впровадження отриманих наукових результатів тощо.

Дослідженню синтезу та взаємовпливу інноваційного розвитку та економічної безпеки як об'єктів управління були присвячені окремі праці фрахівців. Так, першим синтезував ці явища С. Шкарлет, який запропонував комплексну категорію «інноваційний розвиток - економічна безпека». Найближчим до вирішення завдання синтезу інноваційного розвитку та економічної безпеки у складі синтезованого об'єкта управління є дослідження С. Лабунської, в яких розглядається поняття «економічна безпека інноваційної діяльності підприємства», що визначає вплив інноваційної діяльності на стан економічної безпеки підприємства [4, с. 235-236].

Так, реалізація економічної безпеки підприємства ґрунтується на комплексному забезпеченні інноваційних процесів, що спрямовані на підвищення їх ефективності. Активізація впровадження інноваційних процесів на підприємстві залежить від таких основних фракторів, як економічні, технологічні, організаційно-управлінські, правові, фрактори професійної підготовки кадрів. Вплив цих фракторів залежить від спільних зусиль держави, регіональних органів влади та підприємств.

Одними 3 ключових напрямів забезпечення безпеки підприємств є досягнення та підтримання ефективного функціонування інноваційної сорери, від стану якої багато в чому залежить реалізація всієї сукупності регіональних та національних економічних інтересів. Динамічний та прогресивний інноваційний розвиток господарюючих суб'єктів на всіх рівнях сприяє зменшенню значущості ресурсної бази, підвищенню конкурентоспроможності економіки й фрормуванню сучасної моделі економічного зростання, визначає здатність національної економіки переходити на передові технології на власній основі в умовах зростаючої глобалізації світової економіки. Подібно до того, як економічна безпека є базисом системи національної безпеки, безпека в інноваційній сфрері становить основу економічної безпеки підприємства в сучасних умовах господарювання [5; 6].

Основними завданнями ефективної економічної безпеки підприємства мають бути забезпечення фрінансової стійкості та незалежності підприємства; забезпечення технологічної незалежності та досягнення високої конкурентоспроможності технічного потенціалу підприємства; досягнення високої ефективності менеджменту, оптимальної та ефрективної організаційної структури управління підприємством; досягнення високого рівня кваліфрікації персоналу та його інтелектуального потенціалу; мінімізація руйнівного впливу результатів виробничо-господарської діяльності на стан навколишнього середовища; якісна правова захищеність усіх аспектів діяльності підприємства; забезпечення захисту інфрормаційного поля, комерційної таємниці й досягнення необхідного рівня інорормаційного забезпечення роботи всіх підрозділів підприємства; ефективна організація безпеки персоналу підприємства, його капіталу та майна, а також комерційних інтересів [7].

Таким чином, ефективна система економічної безпеки підприємства має включати такі фрункціональні складові (рис. 1):

- фрінансова складова, спрямована на забезпечення фрінансової стійкості підприємства, високих фрінансових результатів діяльності, рентабельності, платоспроможності й ліквідності, прийнятного рівня дебіторсько-кредиторської заборгованості та недопущення банкрутства;

- кадрова складова, що передбачає захист персоналу та нейтралізацію загроз, пов'язаних із ним;

- техніко-технологічна складова, що визначає можливі небезпеки для технологічного потенціалу та розробляє адекватні механізми задля підсилення конкурентоспроможності підприємства;

- ресурсна складова, що полягає в нейтралізації можливих загроз стосовно забезпечення підприємства основними видами ресурсів (матеріальними);

- інорормаційна складова, спрямована на захист інформаційних каналів, збирання інфрормації стосовно внутрішнього й зовнішнього середовища;

- екологічна складова, що забезпечує дотримання чинних екологічних норм, мінімізацію втрат від забруднення довкілля;

- силова складова, що передбачає фрізичний захист майна та ресурсів, зокрема працівників; 


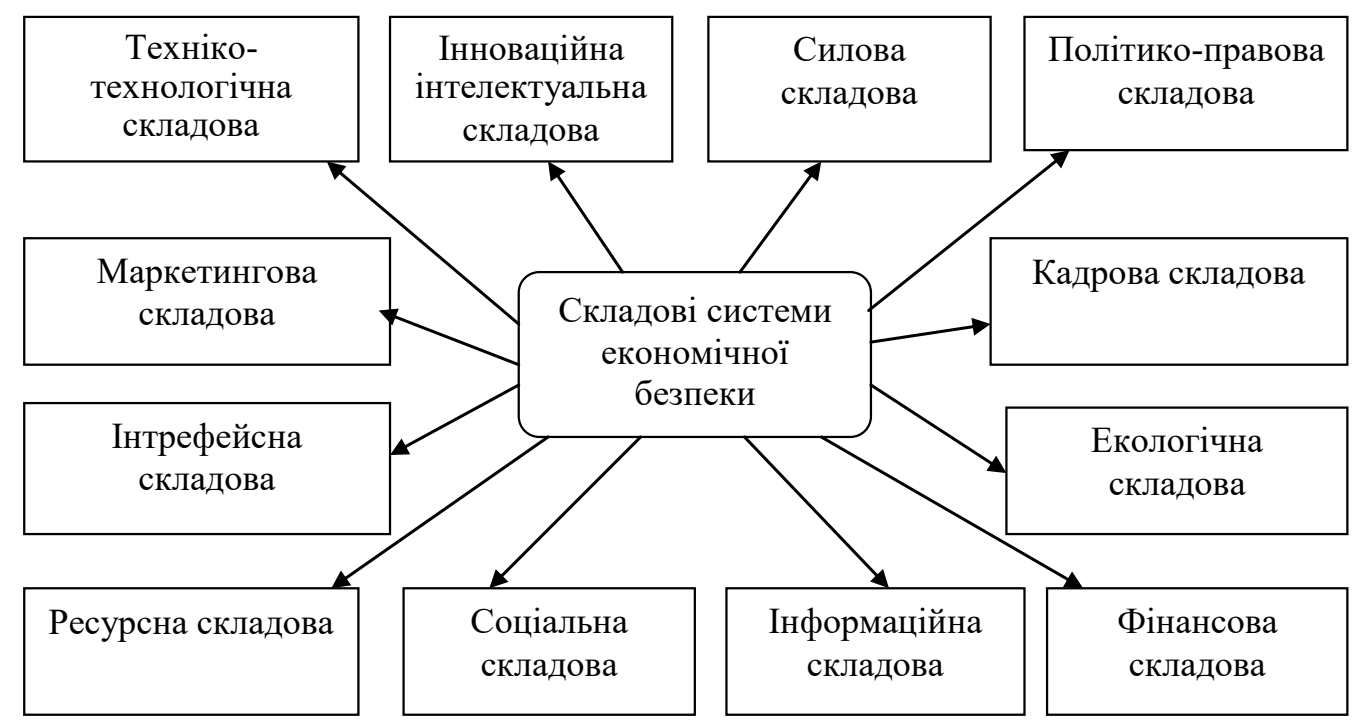

Рис. 1. Функціональні складові системи економічної безпеки підприємства

- політико-правова складова, спрямована на захист правових інтересів підприємства та гнучкість управлінських рішень відповідно до умов політико-правового середовища, що склались;

- інноваційна-інтелектуальна складова, націлена на збереження й розвиток інтелектуального потенціалу підприємства, тобто сукупність прав на інтелектуальну власність або її використання (на відміну від кадрової складової, інноваційноінтелектуальна носієм інтелектуального капіталу визначає не тільки людину, але й інших носіїв нематеріальних активів; інтересами інноваційноінтелектуальної складової $€$ отримання статусу науково-виробничого підприємства, підвищення рівня винахідницької та раціоналізаторської активності, отримання грантів, оперативне впровадження отриманих наукових результатів тощо);

- інтрефрейсна складова, що характеризує надійність взаємодії 3 економічними контрагентами, а саме постачальниками, торговими та збутовими посередниками, інвесторами, споживачами;

- маркетингова складова, що включає ринкові інтереси, а саме збільшення та розширення попиту та обсягів продаж відповідно; прискорення обігу оборотних активів, вдосконалення післяпродажного сервісу; активізацію рекламної діяльності;

- соціальна складова, що передбачає підвищення ефрективності діяльності всіх категорій персоналу (високий рівень цієї фрункціональної складової соціально-економічної безпеки підприємства визначають показники зниження плинності кадрів, удосконалення системи мотивації, підвищення освітньо-профресійного рівня працівників, створення єдиної корпоративної культури, підвищення рівня соціальної відповідальності тощо).

Слід зазначити, що високі результати реалізації інноваційних проєктів та програм можуть досяга- тися за умов фрормування висококваліфрікованої проєктної команди. До їі складу повинні входити, крім дослідників і проєктувальників, спеціалісти 3 інноваційного менеджменту, спроможні просувати нові технології, продукти на ринок, обґрунтувати ефрективні фрінансові, організаційні рішення, досконало володіти методами проєктного управління тощо, тобто інноваційний менеджер є своєрідним посередником між розробниками новітньої ідеї та ринком збуту, забезпечує есективну взаємодію вчених, виробників, інвесторів.

Профресія інноваційного менеджера передбачає поетапне вирішення різнопланових завдань, таких як маркетингове дослідження ринку задля виявлення потреби населення в нових продуктах, послугах, матеріалах, високих технологіях; попередній розрахунок обсягу потреб в інноваційному продукті; пошук (створення) й аналіз інноваційних ідей, що відповідають потребам населення; розроблення проєкту зі впровадження ідеї, маркетингової політики й бізнес-плану; пошук відповідного підприємства, здатного впровадити цю інновацію; спільна робота з конкретним підприємством щодо розроблення технології та техніки виробництва продукції; пошук постачальників необхідного обладнання та сировини, укладання контрактів.

Менеджери, відповідальні за інноваційну діяльність, повинні якісно забезпечувати взаємозв'язок між відповідними структурними підрозділами підприємства й зовнішнім середовищем. До сорери компетенції менеджера входить вирішення питань щодо доцільності проведення науково-дослідних та конструкторських розробок власними силами або силами спеціалізованих організацій, придбання ліцензії. Інноваційний менеджер повинен володіти методами розрахунків грошових потоків від реалізації інноваційних проєктів та у віддаленій перспективі в умовах невизначеності. 
Висновки з проведеного дослідження. Таким чином, інноваційна діяльність є основою забезпечення конкурентоспроможності підприємства, що стає визначальним фактором забезпечення економічної безпеки господарської системи та її сталого розвитку, тому перехід на інноваційну модель розвитку - це не тільки державна задача, але й реальна, об'єктивно наявна потреба будь-якого функціонуючого в умовах ринкової економіки підприємства. Спонукальним мотивом розвитку інноваційної діяльності підприємства є перш за все ринкова конкуренція. Однак багато підприємств хочуть не тільки зберегти свої позиції на ринку, але й зміцнити їх, що неможливо без впровадження інноваційних підходів в усі сорери виробничо-господарської діяльності. Необхідною умовою підвищення ефрективності техніко-технологічної складової економічної безпеки підприємства $€$ кадрове забезпечення, яке сьогодні неможливе без підготовки інноваційних менеджерів. Забезпечення економічної безпеки підприємства не $є$ прерогативою виключно одного відділу, служби або групи осіб. Вона повинна підтримуватися всією внутрішньою структурою підприємства: від керівництва до рядових працівників, усіма ланками й структурами підприємства.

\section{БІБЛІОГРАФІЧНИЙ СПИСОК:}

1. Бурда І. Економічна безпека підприємства та місце в ній кадрової безпеки. Ефективна економіка. 2011. № 10. URL: http://www.economy.nayka.com. ua/?op=1\&z=743 (дата звернення: 25.11.2019).

2. Філиппова С. Аналітичні інструменти системи економічної безпеки суб'єктів господарювання : монографрія. Донецьк : Ноулідж (донецьке відділення), 2012. 179 c.

3. Продіус О. Особливості забезпечення економічної безпеки підприємств в розвинутих країнах. Науковий вісник Міжнародного гуманітарного університету. Серія: Економіка і менеджмент. 2016. № 19. C. 79-82.

4. Волощук Л. Концептуальні засади управління економічно-безпечним інноваційним розвитком промислового підприємства та формування його аналітичних інструментів. Економіка: реалії часу. 2015. № 1 (17). C. 234-241.

5. Гапак Н. Економічна безпека підприємства: сутність, зміст та основи оцінки. Науковий вісник
Ужгородського університету. Серія: Економіка. 2013. Вип. 3 (40). С. 62-65.

6. Троц І. Забезпечення економічної безпеки на підприємстві 3 метою попередження банкрутства. Вісник Житомирського державного технологічного університету. 2012. № 1 (59). С. 223-227.

7. Куделя Л. Формування концепції забезпечення економічної безпеки підприємств. Науковий вісник Херсонського державного університету. 2014. Вип. 5 (2). С. 125-128.

\section{REFERENCES:}

1. Burda I. (2011) Ekonomichna bezpeka pidpryiemstva ta mistse $v$ nii kadrovoi bezpeky [Economic security of the enterprise and its place of personnel security]. Efektyvna ekonomika, vol. 10. Available at: http://www.economy.nayka.com.ua/?op $=1 \& z=743$ (accessed 25 November 2019).

2. Filyppova S. (2012) Analitychni instrumenty systemy ekonomichnoi bezpeky subiektiv hospodariuvannia [Analytical tools for economic security of economic entities]. Donetsk : Noulidzh.

3. Prodius O. (2016) Osoblyvosti zabezpechennia ekonomichnoi bezpeky pidpryiemstv $v$ rozvynutykh krainakh [Features of economic security of enterprises in developed countries]. Naukovyi visnyk Mizhnarodnoho humanitarnoho universytetu. Seriia: Ekonomika $i$ menedzhment, vol. 19, pp. 79-82.

4. Voloshchuk L. (2015) Kontseptualni zasady upravlinnia ekonomichno-bezpechnym innovatsiinym rozvytkom promyslovoho pidpryiemstva ta formuvannia yoho analitychnykh instrumentiv [Conceptual bases of management of economically safe innovative development of industrial enterprise and formation of its analytical tools]. Ekonomika: realii chasu, vol. 1 (17), pp. 234-241.

5. Hapak N. (2013) Ekonomichna bezpeka pidpryiemstva: sutnist, zmist ta osnovy otsinky [Economic security of the enterprise: essence, content and basics of evaluation]. Naukovyi visnyk Uzhhorodskoho universytetu: Seriia: Ekonomika, vol. 3 (40), pp. 62-65.

6. Trots I. (2012) Zabezpechennia ekonomichnoi bezpeky na pidpryiemstvi z metoiu poperedzhennia bankrutstva [Ensuring economic security at the enterprise in order to prevent bankruptcy]. Visnyk Zhytomyrskoho derzhavnoho tekhnolohichnoho universytetu, vol. 1 (59), pp. 223-227.

7. Kudelia L. (2014) Formuvannia kontseptsii zabezpechennia ekonomichnoi bezpeky pidpryiemstv [Formation of the concept of ensuring the economic security of enterprises]. Naukovyi visnyk Khersonskoho derzhavnoho universytetu, vol. 5 (2), pp. 125-128. 
Prodius Oksana

Candidate of Economic Sciences, Associated Professor, Head of Management Department Odessa National Polytechnic University

Tsibulko Andrey

Odessa National Polytechnic University

\section{INTENSIFICATION OF INNOVATIVE ACTIVITIES AS AN IMPORTANT CONSTITUENT OF IMPROVEMENT OF ECONOMIC SECURITY OF THE ENTERPRISE}

The purpose of the article. Against the backdrop of intensification of crisis phenomena of different origin in the modern enterprise management system, there is a need to create a unit whose task is to form management actions to ensure the economic security of the enterprise. The fact that economic security is a universal category, which reflects the security of the subjects of socio - economic relations at all levels, starting with the state and ending with each of its citizens, is a confirmation of the great relevance of this problem. The level of economic security depends on how effectively the management of the company avoids possible threats and eliminates the negative effects of certain negative elements of the external and internal environment. Each of the functional components of economic security should reflect the specifics of the implementation of security measures for specific areas of activity of the enterprise, its structural units or resources. However, in the aggregate, they must complement each other in a harmonious way, creating the preconditions for forming a coherent economic security system. In modern conditions of functioning for business entities is one of the major economic threats enterprise security is a low innovation activity that due to the use of outdated technologies, imperfect ones methods and forms of organization of production and management, absence of the fulfilled mechanisms of innovative activity, inefficient scheme of interaction of scientific institutions with commercial structures, imperfection of organizational and economic mechanism of development of innovations.

Methodology. The main methodological method of research is the system-structural approach, which allows the most effective organization of the search for the solution of the tasks. Also, methods of comparative, functional analysis, classification are used. Theoretical and methodological basis of work were theoretical positions and scientific principles, developed by domestic and foreign specialists in the field of the economic security.

Results. An important functional component of the economic security of the enterprise today is innovationintellectual, which is aimed at preserving and developing the intellectual potential of the enterprise, that is, a set of intellectual property rights or its use. In contrast to the personnel component, not only a person but also other carriers of intangible assets can act in an innovative and intellectual carrier of intellectual capital.

Dynamic and progressive innovative development of business entities at all levels contributes to reducing the importance of the resource base, improving the competitiveness of the economy and the formation of a modern model of economic growth, determines the ability of the national economy to move to advanced technologies on its own basis in the context of growing globalization. Just as economic security is the basis of the national security system, security in the innovation sphere forms the basis of the economic security of the enterprise in the present economic conditions.

Practical implications. Thus, innovation is the basis for ensuring the competitiveness of the enterprise, which in turn becomes a determining factor in ensuring the economic security of the economic system and its sustainable development. Therefore, the transition to an innovative model of development is not only a state task, but also a real, objectively existing need of any operating in the market economy of the enterprise. 